\title{
The Mechanisms of Salinity Tolerance in the Xero-halophyte Blue Panicgrass (Panicum antidotale Retz)
}

\author{
Hamid R. ESHGHIZADEH, Mohammad KAFI*, Ahmad NEZAMI \\ Ferdowsi University of Mashhad, Faculty of Agriculture, Department of Agronomy and Plant Breeding, \\ Mashhad, P.O.Box91775-1163, Iran; mkafi36@yahoo.com (*correspondingauthor)
}

\begin{abstract}
Identifying the physiological traits associated with salt tolerance is important in optimal management of biosaline systems and optimum utilization of saline water resources in dry and saline areas. Therefore, some indices of photosynthetic activity, dry matter production and accumulation of sodium and potassium ions in Blue panicgrass (Panicum antidotale Retz) were evaluated in five levels of salinity treatment $(0,70,140,210$ and $280 \mathrm{mM} \mathrm{NaCl}$ solution) under greenhouse conditions. The results showed that at 28 and 35 days after salt stress, plant leaf area reduced in the highest salinity treatment, 93 and $96 \%$ respectively, compared with control. Leaf stomatal conductance, $\mathrm{CO}_{2}$ fixation and quantum efficiency of photosystem II were decreased by increasing salinity. It caused also a reduction in chlorophyll content $(\mathrm{Chl} a, \mathrm{Chl} b)$ in leaves of Blue panicgrass. Content of carotenoids showed binary patterns to different salinity levels, slightly increased in $70-140 \mathrm{mM} \mathrm{NaCl}$ and decreased again in 210-280 mM, respectively. Increasing levels of salinity, increased sodium content in both roots and shoots but the shoots potassium content decreased. Decline in photosynthesis indices caused the reduction of root and shoot dry weight. This decrease resulted from lower leaf area $\left(\mathrm{r}=0.91^{*}\right)$, lower stomatal conductance $\left(\mathrm{r}=0.78^{* *}\right)$, lower $\mathrm{CO}_{2}$ fixed in photosynthesis $\left(\mathrm{r}=0.63^{*}\right)$, lower quantum efficiency of photosystem II $\left(\mathrm{r}=0.54^{*}\right)$ and lower $\mathrm{Chl} a\left(\mathrm{r}=0.45^{* *}\right)$, respectively. Data analysis base on using stepwise regression introduced leaf area $(\beta=0.560)$, chlorophyll $a$ content $(\beta=0.245)$ and shoot potassium content $(\beta=$ $0.264)$ as main effective components of salinity tolerance in Blue panicgrass.
\end{abstract}

Keywords: chlorophyll fluorescence, $\mathrm{CO}_{2}$ fixation, leaf area, $\mathrm{Na}^{+}$content, stomatal conductance

\section{Introduction}

Salinity in soil or water is one of the major environmental stresses, especially in arid and semi-arid regions, can severely limit production of agriculture systems (Kafi and Khan, 2008). Under this condition, the identification and cultivation of salt tolerant species are functional solution for the effective use of the soils exposed to salinity (Ahmad et al., 2010; Ashraf and Harris, 2005; Kafi and Khan, 2008). Evaluation of the changes in physiological and biochemical characteristics of plants tolerant to various stresses, such as Blue panicgrass (Panicum antidotale Retz) (Ahmad et al., 2010; Ashraf, 2004) provides desirable approaches for studying different aspects of hereditary stress tolerance (Niknam and Mccomb, 2000). Ashraf (2003) reported that imposition of salt stress and water-logging for 46 days caused a significant reduction in growth of $P$. antidotale.

In addition to understand the physiological mechanisms responsible for the salinity tolerance of some species, it is necessary to know whether their growth is being limited by the osmotic, or the toxic effect of the salt within the plant (Munns and Tester, 2008). Salinity stress caused a reduction in chlorophyll content, disorders in the electron transport chain and decrease in photosystem II (PSII) activity which then directly affects the leaf photo- synthesis, carbon metabolism and ultimately economical yield (Sudhir and Murthy, 2004). The light-absorbing pigments such as chlorophylls provide a potential source to produce active oxygen radicals in stress condition and consequently the reducing chlorophyll content lead to a decrease in damage to the photosynthetic system (Ashraf and Harris, 2005).

Salinity stress also decreases carbonic anhydrase enzyme activity due to reduced activity of Rubisco activase (Soussi et al., 1998) and then decreases chlorophyll contents and photosynthetic efficiency. Netondo et al. (2004) stated that increasing sodium chloride concentration in solution medium to $250 \mathrm{mM}$ differently decreased the efficiency of PSII and the rate of electron transfer in two sorghum cultivars. Adversely, Lu et al. (2002) also showed that the salinity had no effects on PSII photochemistry, light inhibition and photosynthetic pigment composition in Suaeda salsa. However, the effect of salinity on the photosynthetic efficiency depends on plants species and intensity of salt stress.

The purpose of the present study was to investigate the photosynthetic activity indices such as stomatal conductance, leaf $\mathrm{CO}_{2}$ fixation, chlorophyll fluorescence parameters, photosynthetic pigments content and biomass production and accumulation of sodium and potassium in the root and shoot of Blue panicgrass as a xero-halophyte after 
60

imposing various levels of salinity in irrigation water and identifying main factors to its salt tolerance.

\section{Materials and methods}

The study was conducted in greenhouse conditions in the Faculty of Agriculture, Ferdowsi University of Mashhad, Iran. Seeds of Blue panicgrass (Panicum antidotale Retz.) were planted in black plastic pots, $23 \mathrm{~cm}$ in diameter and $30 \mathrm{~cm}$ deep were filled with $4 \mathrm{~kg}$ soil (about $92 \%$ sand, $4 \%$ clay, and $4 \%$ silt) in $18^{\text {th }}$ June 2011 . The pots were irrigated until the four-leaf stage by about 200-250

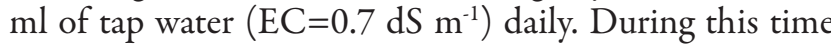
seedlings were eventually thinned over several times and finally kept two plants in each pot. Thus, a control and four saline treatments imposed by irrigation with saline waters contained $70,140,210$ and $280 \mathrm{mM} \mathrm{NaCl}$ in solution, respectively. Sampling and measurements arranged 28 and 35 days after imposing different levels of salinity in irrigation water.

\section{Plant leaf area}

The non-destructive method applied for measuring plant leaf area and was estimated by the following equation:

$\mathrm{y}=0.785 \mathrm{x}+0.164$

$\mathrm{R}^{2}=0.927$

Where consisting: $y$ : Leaf area per plant and $x$ : the multiplying length $\times$ width of the leaf.

\section{Photosynthesis}

Gas exchange and related parameters were measured between $11 \mathrm{am}$ to $1 \mathrm{pm}$ using a portable ADC infra-red gas analyzer (model: LCA4), at PPFD>950 $\mu \mathrm{mol} \mathrm{m}^{-2} \mathrm{~s}^{-1}$; leaf chamber temperature at $33 \pm 2^{\circ} \mathrm{C}$. All measurements were carried out on the intact youngest fully developed leaf, keeping the chamber constantly vertical to solar radiation, till stabilizing gas exchange in the leaf chamber. At least, 10 records were obtained for each leaf after reaching steady state.

\section{Stomatal conductance}

The leaf stomatal conductance $\left(\mathrm{mmol} \mathrm{m}^{-2} \mathrm{~s}^{-1}\right)$ was measured with a steady state porometer (SC-1's Model), with chamber conditions set to ambient.

\section{Chlorophyll fluorescence}

Chlorophyll fluorescence parameters were measured using a leaf chamber fluorometer (Hansatech v. 1.21). Measurements were made on each plant in the four salinity treatments $(n=5)$. Dark adapted fluorescence parameters were measured between 10:00 and 12:00 h, where ambient light intensity was 1,500-1,600 $\mu_{\text {molm }}{ }^{-2} \mathrm{~s}^{-1}$. Plants were dark-adapted for 20 min using a dark adaptation kit designed for this purpose. The minimal fluorescence level in the dark-adapted state $\left(\mathrm{F}_{0}\right)$, and maximal fluorescence
$\left(\mathrm{F}_{\mathrm{m}}\right)$ were measured using a modulated pulse. Values of variable fluorescence $\left(\mathrm{Fv}=\mathrm{F}_{\mathrm{m}}-\mathrm{F}_{0}\right)$ and maximum quantum efficiency of PSII photochemistry $\left(\mathrm{F}_{\mathrm{v}} / \mathrm{F}_{\mathrm{m}}\right)$ were calculated from $\mathrm{F}_{0}$ and $\mathrm{Fm}$.

\section{Chlorophyll content}

Chlorophylls a and b, and total carotenoids were determined according to the method of Dere et al. (1998). Fresh leaves $(0.1 \mathrm{~g})$ were cut and extracted overnight with 95\% ethanol at $0-4^{\circ} \mathrm{C}$. The extracts were centrifuged at 3,000-g for $5 \mathrm{~min}$. Absorbance of the supernatant was read at 666,653 and $470 \mathrm{~nm}$ using a spectrophotometer for chlorophylls a and $b$, and total carotenoids, respectively (Hitachi-220 Japan).

Analysis growth and inorganic elements: The shoots were washed twice in distilled water while ions were removed from the free space of roots by washing for one minute in sorbitol solutions isotonic with the treatments concentration in which the plants were grown. Shoots and roots were dried at $70^{\circ} \mathrm{C}$ for $48 \mathrm{~h}$ to determine their dry weights. Dried and ground plant material $(0.1 \mathrm{~g}$ each of shoot or root) was digested in concentrated $\mathrm{H}_{2} \mathrm{SO}_{4}$ following Wolf (1982) for determining the ionic contents of root and shoot. Cations $\left(\mathrm{Na}^{+}\right.$and $\left.\mathrm{K}^{+}\right)$were determined with a flame photometer (Jenway, PFP-7).

\section{Statistical analysis}

The experiment was designed and analyzed as a complete randomized blocks design with salinity treatment in 5 levels and 3 replications. Statistical significance, where indicated, is at $5 \%$ level of probability as determined by analysis of variance and Fisher's LSD test. Also attributed of measured traits in salt tolerance of Blue panicgrass was evaluated from the data obtained after 28 and 35 days of stress were used by the stepwise regression method using the "statistical software PASW, version 18". In this method, ratios of the total dry weight in the saline to non-saline treatments were as dependent variable and other traits were as independent variables. Simple correlation coefficients $(r)$ between measured traits were achieved by Pearson method.

\section{Results}

\section{Plant leaf area $\left(\mathrm{cm}^{2}\right)$}

Analysis of variance showed significant differences at 99\% probability levels for plant leaf area at 28 and 35 days after imposing various levels of salinity in irrigation water. It was reduced by $90 \%$ in $280 \mathrm{mM}$ sodium chloride when compared to the non-saline treatment, although the strongest reduction observed in $70 \mathrm{mM}$ (Tab. 1)

\section{Stomatal conductance ( $\left.m m o l m^{-2} s^{-1}\right)$}

There were significant differences $(p<0.01)$ for stomatal conductance of leaves at various levels of salinity. The variation between the highest salinity levels in 280 
$\mathrm{mM}$ compared with non saline were $97 \%$ at 28 days after stress and $100 \%$ after 35 days (Tab. 1).

\section{Leaf $\mathrm{CO}_{2}$ fixation rate $\left(\mu \mathrm{mol} \mathrm{m} \mathrm{m}^{-2} \mathrm{~s}^{-1}\right)$}

Analysis of variance showed significant differences at the $1 \%$ probability levels for $\mathrm{CO}_{2}$ fixed by leaf at 28 and 35 days after imposing various levels of salinity in irrigation water. It was reduced by 96 and $100 \%$ in $280 \mathrm{mM}$ sodium chloride when compared to the non-saline treatment after 28 and 35 days (Tab. 1)

\section{Chlorophyll fuorescence parameters}

There were significant differences at the $1 \%$ probability levels for The minimal fluorescence state $\left(\mathrm{F}_{0}\right)$ at various levels of salinity and the lower values belonged to strong salinity (Tab. 1 and 2). However, the difference between the different levels of salinity stress was not significant for $\mathrm{F}_{0}$ after 35 days (Tab. 1).
Analysis of variance showed significant differences for maximal fluorescence $\left(\mathrm{F}_{\mathrm{m}}\right)$ in different levels of salinity, 28 days after imposing stress but was not significant at 35 days. Differences among various salinity treatments for maximum quantum efficiency of PSII photochemistry $(\mathrm{Fv} F \mathrm{Fm})$ were significant at $99 \%$ probability levels 28 days after stress and $95 \%$ at 35 days. Means value of $F_{v} / F_{m}$ was reduced by increasing intensity of salinity stress (Tab. 1).

\section{Photosynthetic pigments $\left(\mu g g^{-1} f w\right)$}

For chlorophyll $a$ content there were significant differences among various levels of salinity stress at $28(p<0.01)$ and 35 days after stress $(p<0.05)$. Chlorophyll $a$ content decreased with increasing salinity levels and leaves had about $62 \%$ and $77 \%$ lower Chlorophyll $a$ in $280 \mathrm{mM}$ sodium chloride compared to non saline treatment, respectively (Tab. 2). Similarly, chlorophyll $b$ content significantly decreased by 65 and $85 \%$ in the presence of $280 \mathrm{mM} \mathrm{sa-}$ linity compared to control. For carotenoids content, $28 \%$

Tab. 1. Mean comparison for leaf area, stomatal conductance, $\mathrm{CO}_{2}$ exchange rate and different parameters of chlorophyll fluorescence of Blue panicgrass (Panicum antidotale Retz) in various salinity levels of irrigation water at 28 and 35 days after stress (DAS)

\begin{tabular}{|c|c|c|c|c|c|c|c|}
\hline DAS & $\begin{array}{l}\text { Salinity } \\
(\mathrm{mM})\end{array}$ & $\begin{array}{l}\text { Leaf area } \\
\qquad\left(\mathrm{cm}^{2}\right)\end{array}$ & $\begin{array}{c}\text { Stomatal } \\
\text { conductance } \\
\left(\mathrm{mmol} \mathrm{m}^{-2} \mathrm{~s}^{-1}\right)\end{array}$ & $\begin{array}{c}\mathrm{CO}_{2} \text { fixed } \\
\left(\mu \mathrm{mol} \cdot \mathrm{m}^{-2} \mathrm{~s}^{-1}\right)\end{array}$ & $\mathrm{F}_{\mathrm{o}}$ & $\mathrm{F}_{\mathrm{m}}$ & $\mathrm{F}_{\mathrm{v}} / \mathrm{F}_{\mathrm{m}}$ \\
\hline \multirow{5}{*}{28} & 0 & 419 & 9.33 & 7.54 & 625 & 2365 & 0.746 \\
\hline & 70 & 83.5 & 7.37 & 2.82 & 606 & 1460 & 0.573 \\
\hline & 140 & 51.1 & 6.03 & 2.33 & 671 & 1500 & 0.520 \\
\hline & 210 & 36.3 & 0.567 & 0.44 & 239 & 338 & 0.330 \\
\hline & 280 & 27.7 & 0.233 & 0.26 & 292 & 300 & 0.066 \\
\hline \multicolumn{2}{|c|}{$\mathrm{LSD}_{50}$} & 36.4 & 2.44 & 2.66 & 169 & 723 & 0.317 \\
\hline \multirow{5}{*}{35} & 0 & 520 & 13.26 & 6.54 & 545 & 2249 & 0.762 \\
\hline & 70 & 141 & 8.10 & 1.82 & 958 & 2403 & 0.603 \\
\hline & 140 & 49.8 & 6.16 & 1.56 & 837 & 1949 & 0.561 \\
\hline & 210 & 48.2 & 5.70 & 0.77 & 522 & 1237 & 0.374 \\
\hline & 280 & 21.2 & 0.00 & 0.00 & 531 & 759 & 0.228 \\
\hline \multicolumn{2}{|c|}{$\mathrm{LSD}_{5 \%}$} & 109 & 3.38 & 2.45 & 466.55 & 999 & 0.301 \\
\hline
\end{tabular}

Tab. 2. Mean comparison photosynthetic pigments, biological yield and root to total weight ratio of Blue panicgrass (Panicum antidotale Retz) in various salinity levels of irrigation water at 28 and 35 days after stress (DAS)

\begin{tabular}{|c|c|c|c|c|c|c|c|c|}
\hline \multirow{2}{*}{ DAS } & \multirow{2}{*}{$\begin{array}{l}\text { Salinity } \\
(\mathrm{mM})\end{array}$} & \multicolumn{3}{|c|}{ Photosynthetic pigments $\left(\mu \mathrm{g} \mathrm{g}^{-1} \mathrm{fw}\right)$} & \multicolumn{3}{|c|}{ Biological yield $\left(\right.$ mg plant $\left.^{-1}\right)$} & \multirow{2}{*}{$\begin{array}{c}\text { Root/Total weight } \\
(\%)\end{array}$} \\
\hline & & Chl $a$ & $\mathrm{Chl} b$ & Cartenoids & Root & Shoot & Total & \\
\hline \multirow{5}{*}{28} & 0 & 10.0 & 9.32 & 1.26 & 2964 & 4656 & 7621 & 39.1 \\
\hline & 70 & 11.6 & 6.41 & 1.00 & 1689 & 1842 & 3531 & 47.6 \\
\hline & 140 & 7.98 & 5.93 & 0.987 & 770 & 1034 & 1805 & 42.7 \\
\hline & 210 & 3.97 & 4.88 & 0.974 & 590 & 643 & 1233 & 46.9 \\
\hline & 280 & 3.72 & 3.23 & 0.318 & 493 & 498 & 991 & 50.9 \\
\hline & $\mathrm{LSD}_{5 \%}$ & 2.65 & 2.28 & 0.647 & 754 & 1132 & 1834 & 14.5 \\
\hline \multirow{5}{*}{35} & 0 & 9.06 & 4.106 & 0.866 & 7478 & 12701 & 20179 & 36.22 \\
\hline & 70 & 5.48 & 3.08 & 1.42 & 1594 & 3275 & 4869 & 34.14 \\
\hline & 140 & 4.72 & 2.31 & 1.64 & 878 & 2304 & 3182 & 27.88 \\
\hline & 210 & 4.63 & 2.27 & 1.35 & 843 & 1686 & 2528 & 34.14 \\
\hline & 280 & 2.21 & 0.628 & 0.622 & 443 & 531 & 974 & 45.52 \\
\hline \multicolumn{2}{|r|}{$\mathrm{LSD}_{5 \%}$} & 1.38 & 0.993 & 0.457 & 2729 & 3070 & 5243 & 14.36 \\
\hline
\end{tabular}


62

different between highest level of salinity and non saline treatments at 28 days after the stress and $74 \%$ at 35 days after stress were recorded.

\section{Dry matter production and allocation ( $m g$ plant $^{-1}$ )}

There were significant differences $(p<0.01)$ in various levels of salinity for both root and shoot dry mater accumulation. The root and shoot dry matter was reduced averaging more than $80 \%$ in $280 \mathrm{mM}$ compared to non saline treatment (Tab. 2). Ratio of root to total dry weight was not significant among treatments but generally it was increased with exceeding salinity (Tab. 2).

\section{$\mathrm{Na}^{+}$and $\mathrm{K}^{+}$content $\left(\mathrm{mg} g^{-1} \mathrm{dry}\right.$ weight)}

$\mathrm{Na}^{+}$content in root was increased significantly by increasing salinity, averaging $11 \mathrm{mg} \mathrm{g}^{-1}$ more in $280 \mathrm{mM}$ compared to non saline treatment. Similarly the shoot $\mathrm{Na}^{+}$ content was significantly increased by 70.6 and $42.7 \mathrm{mg} \mathrm{g}^{-1}$ at 28 and 35 days after stress in $280 \mathrm{mM}$ salinity compared to control (Tab. 3). In addition, there were significant differences $(p<0.01)$ among various levels of salinity stress for $\mathrm{K}^{+}$content of both root and shoot. The $\mathrm{K}^{+}$content of root in $280 \mathrm{mM}$ was $6.4 \mathrm{mg} \mathrm{g}^{-1}$ more than non saline treatment at 28 days after stress and adversely $43.5 \mathrm{mg}$ lower at 35 days after. The shoot $\mathrm{K}^{+}$content was significantly decreased by 21.4 and $24.6 \mathrm{mg}$ at 28 and 35 days after stress in $280 \mathrm{mM}$ compared to control, respectively (Tab. 3).

\section{$\mathrm{Na}^{+} / \mathrm{K}^{+}$ratio}

As shown in Tab. 3, there were significant differences in $\mathrm{Na}^{+} / \mathrm{K}^{+}$ratio of root and shoot among various levels of salinity stress. $\mathrm{Na}^{+} / \mathrm{K}^{+}$ratio of root was 2.8 times more in $280 \mathrm{mM}$ sodium chloride compared to non saline treatment at 28 days after salinity stress, but there was not a significant difference at 35 days after salinization. After 28 and 35 days, shoot $\mathrm{Na}^{+} / \mathrm{K}^{+}$ratio in $280 \mathrm{mM}$ sodium

Tab. 3. Mean comparison of $\mathrm{Na}+$ and $\mathrm{K}+$ content and $\mathrm{Na}^{+} / \mathrm{K}^{+}$ratio in the root and shoot of Blue panicgrass (Panicum antidotale Retz) in various salinity levels of irrigation water at 28 and 35 days after stress (DAS)

\begin{tabular}{|c|c|c|c|c|c|c|c|}
\hline \multirow[t]{2}{*}{ DAS } & \multirow{2}{*}{$\begin{array}{c}\text { Salinity } \\
(\mathrm{mM})\end{array}$} & \multicolumn{2}{|c|}{$\begin{array}{l}\mathrm{Na}^{+} \text {content } \\
\left(\mathrm{mg} \mathrm{g}^{-1} \mathrm{dw}\right)\end{array}$} & \multicolumn{2}{|c|}{$\begin{array}{l}\mathrm{K}^{+} \text {content } \\
\left(\mathrm{mg} \mathrm{g}^{-1} \mathrm{dw}\right)\end{array}$} & \multicolumn{2}{|c|}{$\mathrm{Na}^{+} / \mathrm{K}^{+}$} \\
\hline & & Root & Shoot & Root & Shoot & Root & Shoot \\
\hline \multirow{5}{*}{28} & 0 & 8.20 & 7.38 & 12.9 & 39.9 & 0.655 & 0.634 \\
\hline & 70 & 11.4 & 11.3 & 22.9 & 21.8 & 1.26 & 2.27 \\
\hline & 140 & 12.3 & 28.6 & 5.39 & 18.8 & 2.29 & 4.98 \\
\hline & 210 & 16.7 & 67.7 & 8.50 & 19.2 & 2.09 & 3.63 \\
\hline & 280 & 20.8 & 78.0 & 6.50 & 18.5 & 3.46 & 4.63 \\
\hline \multicolumn{2}{|c|}{$\mathrm{LSD}_{5 \%}$} & 8.27 & 51.4 & 3.42 & 10.3 & 1.79 & 4.46 \\
\hline \multirow{6}{*}{35} & 0 & 3.67 & 6.80 & 4.46 & 37.2 & 0.867 & 0.191 \\
\hline & 70 & 7.01 & 13.4 & 7.29 & 17.3 & 0.961 & 0.845 \\
\hline & 140 & 12.8 & 23.1 & 54.4 & 12.8 & 0.239 & 1.79 \\
\hline & 210 & 14.5 & 24.0 & 58.0 & 12.3 & 0.260 & 1.96 \\
\hline & 280 & 15.2 & 49.5 & 48.2 & 12.6 & 0.330 & 4.02 \\
\hline & & 4.45 & 8.14 & 19.4 & 8.78 & 0.251 & 0.687 \\
\hline
\end{tabular}

Tab. 4. Statistical summary of the stepwise regression results for the salinity tolerance index of Blue panicgrass

\begin{tabular}{cccccc}
\hline Model & Variable & Adjusted R square & df & F & P-value \\
\hline Step1 & Plant Leaf Area (PLA) & 0.829 & 1 & 136 & 0.000 \\
Step2 & Chlorophyll $a($ CHA $)$ & 0.903 & 1 & 125 & 0.000 \\
Step3 & K Content in Shoot $($ KCS $)$ & 0.921 & 1 & 101 & 0.000 \\
\hline
\end{tabular}

Tab. 5. The estimated coefficients of salinity stress tolerance model of Blue panicgrass in the stepwise regression method

\begin{tabular}{cccccc}
\hline & Model & Beta coefficient $(\beta)$ & Adjusted Beta coefficient $(\beta)$ & t & P-value \\
\hline \multirow{2}{*}{ Step1 } & Intercept & 0.115 & - & 3.34 & 0.002 \\
& Plant leaf area (PLA) & 0.002 & 0.911 & 11.6 & 0.000 \\
\hline \multirow{3}{*}{ Step2 } & Intercept & -0.066 & - & -1.37 & 0.181 \\
& Plant leaf area (PLA) & 0.001 & 0.732 & 10.2 & 0.000 \\
& Chlorophyll a (CHA) & 0.036 & 0.324 & 4.51 & 0.000 \\
\hline \multirow{5}{*}{ Step3 } & Intercept & -0.151 & - & -2.70 & 0.012 \\
& Plant leaf area (PLA) & 0.001 & 0.560 & 5.85 & 0.000 \\
& Chlorophyll a (CHA) & 0.027 & 0.245 & 3.34 & 0.003 \\
& K content in shoot (KCS) & 0.009 & 0.264 & 2.48 & 0.020 \\
\hline
\end{tabular}


chloride were 3.99 and 3.88 times more than non saline treatment (Tab. 3).

\section{Stepwise multiple regression}

Results of stepwise regression showed that the plant leaf area (PLA), Chlorophyll $a$ (CHA) and $\mathrm{K}$ content in shoot (KCS) can put in model during three steps (Tab. 4). Also based on beta values in Tab. 5, the regression equation can be written as follow:

\section{$S T I=-0.151+0.001 P L A+0.027 C H A+0.009 K C S$}

Where consisting: STI: Salinity tolerance index; PLA: Plant leaf area; CHA: Chlorophyll $a$ and KCS: K content in shoot. Base on beta value, one unit variation in the plant leaf area will change 0.560 units in standard division of salinity tolerance index as the dependent variable, while one unit variation in the chlorophyll $a$ (CHA) and $\mathrm{K}$ content in shoot (KCS) will change 0.245 and 0.264 units in this index, respectively.

\section{Discussion}

Although the halophyte species are naturally adapted to the salinity, but salt tolerance of them are strongly influenced by the origin of ecotype and plant development stage (Megdiche et al., 2007). Study on photosynthetic activity indicators of Blue panicgrass in this study showed that increasing the salinity reduced plant leaf area and there was a relatively rapid decline slope, especially in the treatment of $70 \mathrm{mM}$ (Tab. 1). However, different between 0 and $70 \mathrm{mM} \mathrm{NaCl}$ treatments used in this experiment was $4.52 \mathrm{dS} \mathrm{m}^{-1}$ but the accumulation of salts in the soil over time, increased levels of stress to the plants and thus was not unexpected relatively high reduction in the leaf area. Muuns et al. (2003) stated that over time and with increasing the salinity, was reduced the cell growth and division and final size of plant leaves. Munns et al. (2006) also reported reduction of leaf growth by accumulation of salts around the roots that mainly due to the osmotic effect of salinity.

Leaf stomatal conductance, $\mathrm{CO}_{2}$ fixed by leaf and maximum quantum efficiency of PSII photochemistry $\left(\mathrm{F}_{\mathrm{v}} \mathrm{F}_{\mathrm{m}}\right)$ were declined with increasing salinity, that are as major factors in reducing photosynthetic production and decreased allocation to the development of various organs (Munns and James, 2003). Ashraf (2004) also noted that net $\mathrm{CO}_{2}$ assimilation and stomatal conductance of Blue panicgrass were positively associated and the former variable also had a strong positive relationship with transpiration. The positive correlation coefficients between leaf area and $\mathrm{CO}_{2}$ fixation rate $\left(\mathrm{r}=0.81^{* *}\right)$, leaf stomatal conductance $\left(\mathrm{r}=0.76^{* *}\right)$ and efficiency of PSII photochemistry $\left(r=0.58^{* *}\right)$ also emphasizes this issue (Tab. 6). Increase in salinity decreased chlorophyll concentration (Tab. 4) that indicate that other factors also reduce the efficiency of photosynthetic activity and ultimately reduce development of the plant's leaf area (Munns et al., 2006). Leaf chlorophyll content showed strong reduction in the Cakile maritima as halophyte that was more evident in the salt sensitive ecotypes (Megdiche et al., 2007). Positive correlation between chlorophyll $a$ and $b$ with other traits was shown the potential role of these pigments to protect capacity for photosynthesis and plant biomass accumula-

Tab. 6. Simple correlation coefficients between different measured traits of Blue panicgrass under different levels of salinity stress

\begin{tabular}{|c|c|c|c|c|c|c|c|c|c|c|c|c|c|c|c|c|c|c|c|}
\hline & 1 & 2 & 3 & 4 & 5 & 6 & 7 & 8 & 9 & 10 & 11 & 12 & 13 & 14 & 15 & 16 & 17 & 18 & 19 \\
\hline 1 & 1 & & & & & & & & & & & & & & & & & & \\
\hline 2 & $0.76^{\circ}$ & 1 & & & & & & & & & & & & & & & & & \\
\hline 3 & $0.14^{\mathrm{ns}}$ & $0.43^{\circ}$ & 1 & & & & & & & & & & & & & & & & \\
\hline 4 & $0.57^{\prime \prime}$ & $0.75^{*}$ & $0.75^{\circ}$ & 1 & & & & & & & & & & & & & & & \\
\hline 5 & $0.58^{* *}$ & $0.74^{*}$ & $0.47^{*}$ & $0.86^{\circ}$ & 1 & & & & & & & & & & & & & & \\
\hline 6 & $0.81^{*}$ & $0.66^{*}$ & $0.23^{\mathrm{ns}}$ & $0.65^{* *}$ & $0.64^{*}$ & 1 & & & & & & & & & & & & & \\
\hline 7 & $0.55^{\circ}$ & $0.68^{*}$ & $0.23^{\mathrm{ns}}$ & $0.54^{*}$ & $0.67^{*}$ & $0.66^{\circ}$ & 1 & & & & & & & & & & & & \\
\hline 8 & $0.43^{\prime \prime}$ & $0.37^{\circ}$ & $-0.02^{\mathrm{ns}}$ & $0.32^{\mathrm{ns}}$ & $0.41^{\circ}$ & $0.66^{\circ}$ & $0.75^{\circ}$ & 1 & & & & & & & & & & & \\
\hline 9 & $0.07^{\mathrm{ns}}$ & $0.35^{\mathrm{ns}}$ & $0.57^{\prime \prime}$ & $0.63^{\prime \prime}$ & $0.65^{\prime \prime}$ & $0.18^{\mathrm{ns}}$ & $0.18^{\mathrm{ns}}$ & $0.05^{\mathrm{ns}}$ & 1 & & & & & & & & & & \\
\hline 10 & $0.91^{*}$ & $0.78^{* \prime}$ & $0.17^{\mathrm{ns}}$ & $0.52^{*}$ & $0.54^{\prime \prime}$ & $0.65^{\prime \prime}$ & $0.43^{\circ}$ & $0.14^{\mathrm{ns}}$ & $0.07^{\mathrm{ns}}$ & 1 & & & & & & & & & \\
\hline 11 & $0.88^{* \prime}$ & $0.76^{*}$ & $0.02^{\mathrm{ns}}$ & $0.42^{\circ}$ & $0.52^{\circ}$ & $0.58^{* *}$ & $0.47^{\circ}$ & $0.20^{\mathrm{ns}}$ & $0.00^{\mathrm{ns}}$ & $0.95^{\circ}$ & 1 & & & & & & & & \\
\hline 12 & $0.91^{*}$ & $0.78^{* *}$ & $0.12^{\mathrm{ns}}$ & $0.49^{*}$ & $0.54^{\circ}$ & $0.63^{* *}$ & $0.45^{\circ}$ & $0.17^{\mathrm{ns}}$ & $0.05^{\mathrm{ns}}$ & $0.99^{* *}$ & $0.98^{* *}$ & 1 & & & & & & & \\
\hline 13 & $-0.24^{\mathrm{ns}}$ & $-0.40^{\mathrm{ns}}$ & $-0.71^{*}$ & $-0.61^{*}$ & $-0.40^{\circ}$ & $-0.23^{\mathrm{ns}}$ & $-0.06^{\mathrm{ns}}$ & $0.16^{\mathrm{ns}}$ & $-0.59^{*}$ & $-0.32^{\mathrm{ns}}$ & $-0.12^{\mathrm{ns}}$ & $-0.25^{\mathrm{ns}}$ & 1 & & & & & & \\
\hline 14 & $-0.68^{* *}$ & $-0.78^{*}$ & $-0.49^{* *}$ & $-0.76^{*}$ & $-0.74^{\prime \prime}$ & $-0.63^{*}$ & $-0.62^{*}$ & $-0.31^{\mathrm{ns}}$ & $-0.36^{\mathrm{ns}}$ & $-0.68^{\prime \prime}$ & $-0.63^{*}$ & $-0.67^{*}$ & $0.42^{\circ}$ & 1 & & & & & \\
\hline 15 & $-0.51^{*}$ & $-0.75^{\prime \prime}$ & $-0.48^{* *}$ & $-0.72^{*}$ & -0.76 & $-0.55^{\prime \prime}$ & $-0.65^{*}$ & $-0.27^{\mathrm{ns}}$ & $-0.58^{* \prime}$ & $-0.48^{\prime \prime}$ & $-0.44^{\circ}$ & $-0.47^{*}$ & $0.43^{\circ}$ & $0.82^{*}$ & 1 & & & & \\
\hline 16 & $-0.35^{\mathrm{ns}}$ & $-0.21^{\mathrm{ns}}$ & $0.08^{\mathrm{ns}}$ & $-0.16^{\mathrm{ns}}$ & $-0.26^{\mathrm{ns}}$ & $-0.36^{\mathrm{ns}}$ & $-0.48^{*}$ & $-0.56^{\circ}$ & $0.24^{\mathrm{ns}}$ & $-0.27^{\mathrm{ns}}$ & $-0.32^{\mathrm{ns}}$ & $-0.29^{\mathrm{ns}}$ & $-0.29^{\mathrm{ns}}$ & $-0.22^{\mathrm{ns}}$ & $-0.03^{\mathrm{ns}}$ & 1 & & & \\
\hline 17 & $0.82^{\prime \prime}$ & $0.56^{\circ}$ & $0.06^{\mathrm{ns}}$ & $0.45^{\circ}$ & $0.45^{\circ}$ & $0.81^{*}$ & $0.66^{\circ}$ & $0.68^{* \prime}$ & $-0.08^{\mathrm{ns}}$ & $0.63^{*}$ & $0.61^{*}$ & $0.63^{\prime \prime}$ & $-0.08^{\mathrm{ns}}$ & $-0.55^{\circ}$ & $-0.35^{\mathrm{ns}}$ & $-0.51^{*}$ & 1 & & \\
\hline 18 & $-0.23^{*}$ & $-0.37^{*}$ & $-0.45^{\circ}$ & $-0.45^{\circ}$ & $-0.40^{\circ}$ & $-0.21^{\mathrm{ns}}$ & $-0.13^{\text {ns }}$ & $0.15^{\mathrm{ns}}$ & $-0.50^{* \prime}$ & $-0.24^{\mathrm{ns}}$ & $-0.17^{\mathrm{ns}}$ & $-0.21^{\mathrm{ns}}$ & $0.53^{\prime \prime}$ & $0.58^{* \prime}$ & $0.69^{*}$ & $-0.58^{\prime \prime}$ & $-0.07^{\text {ns }}$ & 1 & \\
\hline 19 & $-0.57^{\prime \prime}$ & $-0.64^{*}$ & $-0.38^{\circ}$ & $-0.58^{* \prime}$ & $-0.57^{*}$ & $-0.42^{\circ}$ & $-0.43^{* \prime}$ & $-0.17^{\mathrm{ns}}$ & -0.44 & $-0.55^{*}$ & $-0.49^{*}$ & $-0.53^{*}$ & $0.42^{\circ}$ & $0.71^{*}$ & $0.69^{* *}$ & $-0.02^{\mathrm{ns}}$ & $-0.49^{*}$ & $0.62^{*}$ & 1 \\
\hline
\end{tabular}

ns, "and ": Non significant, significant at $5 \%$ and $1 \%$ levels of probability, respectively; Numbers 1 to 19 , respectively, represent: 1 : Plant leaf area ; 2: Stomatal conductance; 3: Fo; 4: Fm; 5: Fv / Fm; 6: CO2 fixation by leaves; 7: Chlorophyll a concentration; 8 Chlorophyll b concentration; 9: Carotenoids concentration; 10: Shoot dry matter; 11: Root dry matter; 12: Total dry matter; 13: Root /Total weight ratio; 14: Root sodium concentration; 15: Shoot sodium concentration; 16: Root potassium concentration; 17: Shoot potassium concentration; 18: Root sodium to potassium ratio; 19: Shoot sodium to potassium ratio 
64

tion (Tab. 6). When halophytes such as Paspalum vaginatum Swartz (Lee et al., 2005), P. antidotale (Ashraf, 2003) and field crop, including wheat (Bajji et al., 2001), were exposed to salinity stress, net photosynthesis, stomatal conductance and chlorophyll content were reduced.

The total content of carotenoids followed a binary pattern in response to different intensities of salinity and relatively increased in 70 and $140 \mathrm{mM}$ but adversely was associated with decreased in 210 and $280 \mathrm{mM}$ salt treatments (Tab. 2). Also there were significant positive correlation between total carotenoids and different parameters of chlorophyll fluorescence (Tab. 6).

Concurrent with the decline in leaf photosynthetic characteristics, root and shoot dry weight was also reduced (Tab. 1). This decrease resulted from lower leaf surfaces $\left(\mathrm{r}=0.91^{* *}\right)$, lower stomatal conductance $\left(\mathrm{r}=0.78^{* *}\right)$, lower $\mathrm{CO}_{2}$ fixed $\left(\mathrm{r}=0.63^{* *}\right), \mathrm{r}=0.91^{* *}$ quantum efficiency of PSII $\left(\mathrm{r}=0.54^{* *}\right)$ and lower leaf chlorophyll $a\left(\mathrm{r}=0.45^{* *}\right)$, respectively (Tab. 6).

With increasing salinity, sodium concentration in the root and shoot increased consequently sodium to potassium ratio decreased (Tab. 6). However, toxicity of sodium ion after increasing $\mathrm{Na}^{+} / \mathrm{K}^{+}$ratio in the root and shoot are a possible reason for the decline in photosynthesis rate and dry matter yield (Munns and Tester, 2008).

Negative correlation between total dry matter yield and sodium concentrations of root $\left(\mathrm{r}=-0.67^{* *}\right)$ and shoot $\left(\mathrm{r}=-0.47^{* *}\right)$ and positive correlation between total dry matter yield and $\mathrm{K}^{+}$concentrations of shoot $\left(\mathrm{r}=0.63^{* *}\right)$ is emphasized (Tab. 6). These results are consistent with findings of other researchs on Cakile maritime (Megdiche et al., 2007) and Hordeum vulgare genotypes (Taghipour and Salehi, 2008).

\section{Conclusions}

Although, in the study of Ashraf (2003) growth of $P$. antidotale adapted to saline habitats was associated with higher net $\mathrm{CO}_{2}$ assimilation and stomatal conductance, but under the present experiment conditions stepwise regression showed that leaf area, chlorophyll a content and shoot $\mathrm{K}^{+}$content are the main components of salt tolerance in Blue panicgrass.

\section{References}

Ahmad MS, Ashraf M, Ali Q (2010). Soil salinity as a selection pressure is a key determinant for the evolution of salt tolerance in Blue Panic grass (Panicum antidotale Retz.). Flora 205:37-45.

Ashraf M, Harris PJ (2005). Abiotic stresses: plant resistance through breeding and molecular approaches. Haworth Press, New York.

Ashraf M (2003). Relationships between leaf gas exchange characteristics and growth of differently adapted populations of Blue Panic Grass (Panicum antidotale Retz.) under salinity or water logging. Plant Sci 165:69-75.

Ashraf M (2004). Some important physiological selection criteria for salt tolerance in plants. Flora 199:361-376.

Bajji M, Lutts S, Kinet JM (2001). Water deficit effects on solute contribution to osmotic adjustment as a function of leaf ageing in three durum wheat (Triticum durum Desf.) cultivars performing differently in arid conditions. Plant Sci 160:669-681.

Dere S, Gunes T, Sivaci R (1998). Spectrophotometric determination of chlorophyll-a, $\mathrm{b}$ and total carotenoid contents of some algae species using different solvents. Turkish J Bot 22:13-17.

Kafi M, Khan MA (2008). Crop and forage production using saline waters. Daya Publishers, New Delhi, India.

Lee G, Carrow RN, Duncan RR (2005). Criteria for assessing salinity tolerance of the halophytic turf grass seashore Paspalum. Crop Sci 45:251-258.

Lu C, Qiu N, Lu Q (2002). Does salt stress lead to increased susceptibility of photosystem II to photoinhibition and changes in photosynthetic pigment composition in halophyte Suaeda salsa grown outdoors? Plant Sci 63:10631068.

Megdiche W, Ben Amor N, Debez A, Hessini K, Ksouri R, Zuily-Fodil Y, Abdelly C (2007). Salt tolerance of the annual halophyte Cakile maritima as affected by the provenance and the developmental stage. Acta Physiol Planta 29:375-384.

Munns R, James RA (2003). Screening methods for salinity tolerance: A case study with tetraploid wheat. Plant Soil 253:201-218.

Munns R, Tester M (2008). Mechanisms of salinity tolerance. Ann Rev Plant Bio 59:651-681.

Munns R, James RA, Läuchli A (2006). Approaches to increasing the salt tolerance of wheat and other cereals. J Exp Bot 57:1025-1043.

Netondo GW, Onyango JC, Beck E (2004). Sorghum and salinity: II. Gas exchange and chlorophyll fluorescence of sorghum under salt stress. Crop Sci 44:806-811.

Niknam SR, Mccomb J (2000). Salt Tolerance Screening of Selected Australian Woody Species: A Review. Forest Ecol Manage 139:1-19.

Soussi M, Ocan A, Lluch C (1998). Effects of salt stress on growth, photosynthesis and nitrogen fixation in chick-pea (Cicer arietinum L.). J Exp Bot 49:1329-1337.

Sudhir P, Murthy SDS (2004). Effects of salt stress on basic processes of photosynthesis. Photosynthetica 42: 481-486.

Taghipour F, Salehi M (2008). The study of salt tolerance of Iranian barley (Hordeum vulgare L.) genotypes in seedling growth stages. Amer Eura J Agric Environ Sci 4:525-529.

Wolf B (1982). An improved universal extracting solution and its use for diagnosing soil fertility. Comm Soil Sci Plant Anal 13:1005-1033. 